\title{
CONSIDERATION ON THE ATMOSPHERIC PRECIPITATIONS IN THE CENTRAL PLATEAU OF MOLDAVIA
}

\author{
Tiron Mihăiță ${ }^{1}$
}

Key words: precipitation, Central Moldavian Plateau

\begin{abstract}
Atmospheric precipitation represents one of the important climatic parameters that characterize the individuality of the climate of the regions, by its decisive influence on the climatic characteristics, but also on the geographic landscape. Therefore, this parameter is important from a theoretical point of view, but also a practical importance through the direct impact and the modifications that they bring to the activity of some important fields such as agriculture, transport, construction, tourism etc. In the present paper is intended to contribute to the scientific knowledge of this important climatic element in the Central Moldavian Plateau. The average of thew annual, semestrial and monthly precipitation quantities from the Central Moldovan Plateau were analyzed. The average annual values of the atmospheric precipitation in the Central Moldavian Plateau are slightly lower than in other regions of Romania (except for the Iași Coast), due to the continental influence, which is also manifested by the high percentage of the average precipitation in the warm semester and by summer. June is the month with the highest average amounts of rainfall, and February (isolated January), the month with the smallest average quantities.
\end{abstract}

\section{Introduction}

The evolution of the various parameters on a multiannual, semestrial, seasonal and monthly basis, which will be presented below, analyzes important aspects of the precipitation distribution, useful mainly for the field of agriculture, where it is especially important to the quantities that have fallen in the warm semester where the amount of water is necessary for vegetation development.

Besides a quantitative characterization at annual average as well as on a semester and seasons basis, we also considered the precipitation distribution on the Moldavian Plateau in representative months, considering that in this region the pluviometric characteristics are generated mainly by the cyclonic activity,

${ }^{1}$ Al.I.Cuza University, Geography and Geology Faculty, Iasi, Romania 
which gives a random character to the spatial and temporal distribution of atmospheric precipitation, as is also stated in the works elaborated for this area. The area is sheltered from the Atlantic by the major west and central Europe, the Apuseni Mountains and the Eastern Carpathians. Instead, the area is exposed to Mediterranean cyclones and retrograde cyclones and of the action of continental air masses in the east, north-east and north. As a result of these major factors, the studied area receives moderate amounts of rainfall (Erhan, 1988).

As a distribution at the plateau surface, the annual, semester, seasonal and monthly average rainfall rates show an increase, generally, in relation to the altitude, but there is a decrease in the western area, to Siret Culoir, of the region, with more efficient shelter westwards by approaching the Moldavian Subcarpathians and Eastern Carpathians, which diminishes the action of some passages on the fronts of the Mediterranean cyclones. The smallest amounts of precipitation, however, are located at the shelter of the north-western circulation, in the Prut Culoir.

\section{Methodology}

There are used data from meteorological stations A.N.M. from the Central Moldavian Plateau and the surrounding area, for the period 1961-2016, as well as data from the rainfall stations of the Prut-Bârlad Basin Water Administration. Data strings over 30 years meet WMO representativeness criteria. Since there was no station in the lower area of the Prut River Culoir, were used data from the Leova meteorological station, from the Republic of Moldova. The used meteorological stations and the rainfall stations have provided good climatic coverage of the studied area, both horizontally and in altitude (from $45 \mathrm{~m}$ altitude, Leova, to 395 m, Bârnova).

The cartographic representations were made using the TNT Mips software with reference to the Numerical Model of the Land. Thus, by extrapolating the rainfall data with the help of these tools, the thematic maps with the hypsometry of the studied area and the distribution of the climatic elements resulted.

\section{Annual regime}

The annual regime of the atmospheric precipitation in the Central Moldavian Plateau for the pluviometric stations is presented below and the spatial distribution map of the annual averages of precipitations on meteorological and pluviometric stations in Fig. 1.

As we could see in Fig. 1, the increase in the average annual rainfall is produced with altitude, but also to the west and especially to the north. The Iaşi 
Coast, with an altitude of about $350 \mathrm{~m}$ in addition to the Bahlui and Bahluieț valley, with a high degree of massiveness and continuity, constitutes a

Tab. 1. The multiannual average rainfall $(\mathrm{mm})$ at the pluviometric stations in the Central Moldavian Plateau

\begin{tabular}{|c|c|c|c|c|c|c|c|}
\hline Station & Ciurbești & Ezăreni & Solești & Bârnova & Băcești & Chiperești & Codăiești \\
\hline Average & 494.7 & 526.5 & 465.6 & 791.5 & 566.4 & 527.7 & 528.1 \\
\hline & & & înceni & Lipova & Prisăcani & Satu Nou & \\
\hline
\end{tabular}

notable obstacle to the masses of air that have, in the central area of Moldova, to the predominant northwestern direction north-west. In its eastern part of the Iași Coast, there is added a condensation from the many condensation cores generated by the city of Iasi and its metropolitan area.

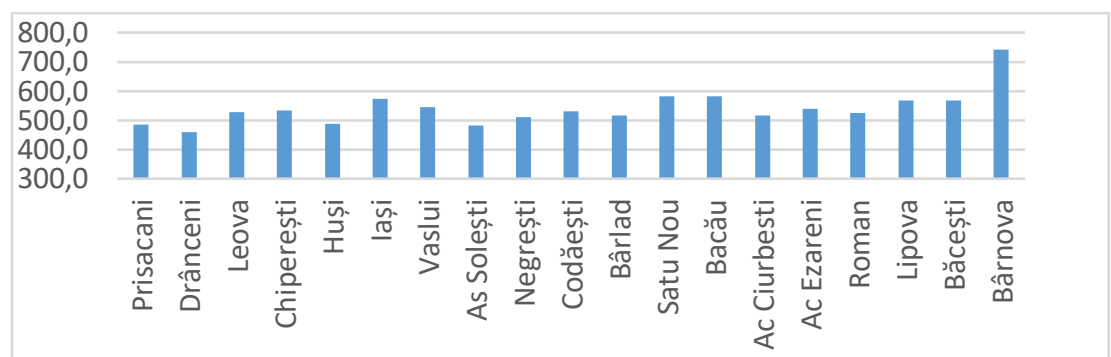

Fig. 1. Distribution of annual average precipitation $(\mathrm{mm})$ at meteorological stations and pluviometric stations in Central Moldavian Plateau

As can be seen in the map above (Fig. 2), the average annual quantities are moderate at contact with Siret Corridor, where although the western slope is high and massive, its location in the shadow of Pietricica, makes it feel westward effects and light foehn processes. The process is exacerbated to the east, after crossing each high peak, which in the Central Moldavian Plateau, has in most cases north-south orientation. 


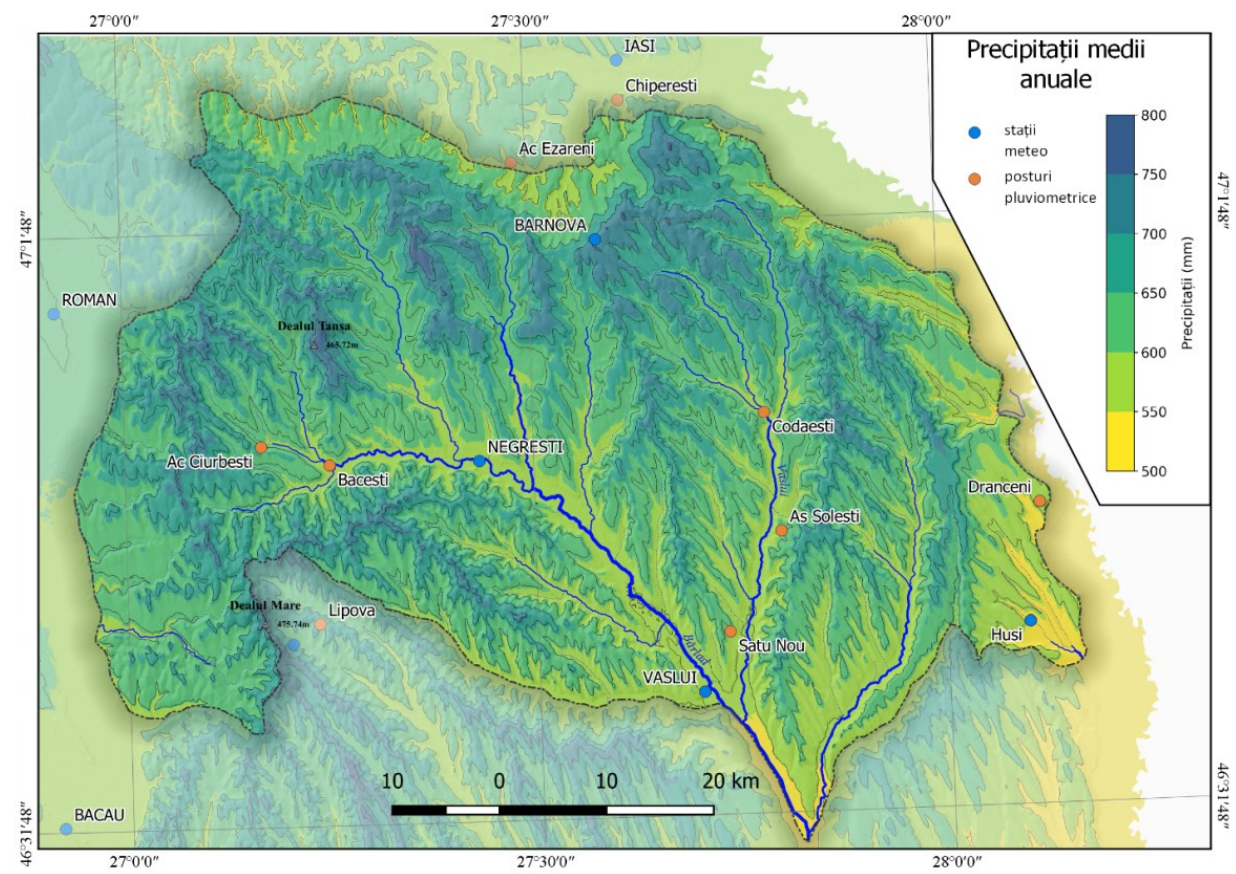

Fig. 2. Annual average of the precipitation in the Central Moldavian Plateau (19612016)

\section{Semester regime}

The distribution of the atmospheric precipitation at the semester level is first and foremost applicable, given that precipitation is the deciding factor for the agricultural field and an important factor in other socio-human areas that takes place with a specific seasonality.

Tab. 2. The average values of atmospheric precipitation in the warm semester ( $\mathrm{mm})$

\begin{tabular}{|c|c|c|c|c|c|c|c|}
\hline Station & Prisacani & Drânceni & Leova & Chiperești & Huși & Iași & Vaslui \\
\hline Average & 323.8 & 291.7 & 327.0 & 354.3 & 316.0 & 381.4 & 358.9 \\
\hline Station & Negrești & SatuNou & Bacău & Ciurbești & Ezăreni & Solești & Roman \\
\hline Aveerage & 351.7 & 374.7 & 404.3 & 345.1 & 361.8 & 325.5 & 380.4 \\
\hline Station & Codăești & Bârlad & Lipova & Băcești & Bârnova & & \\
\hline Average & 348.9 & 335.6 & 371.0 & 379.9 & 468.0 & & \\
\hline
\end{tabular}


Warm semester. The annual regime of average monthly precipitation is characterized by large quantities at the end of spring and summer, the maximum being placed in June and a minimum in the cold seasons, in February (with some exceptions, with minimum în January). This, cumulatively, also decides the semestrial regime (Tab. 2).

The precipitation regime and the large quantities in the warm semester can be explained against the backdrop of the cyclonic barrel centers that bring in wet air from the Atlantic, but during the warm semester the precipitations are produced also, in important quantities by the processes from the European continent and convective precipitations (but with low percent, Hârjoabă, Crețu, 1984), under the anticyclone and cyclonal barrel regime, against the background of a wetland, high surface area and an increase in the temperature value, which can cause convective precipitation, highlighting the uneven spatial and temporal nature of precipitation. Obviously, the precipitation with regional genesis, due to the evapotranspiration on the surface of the European land (soil, vegetation, water mirrors, anthropogenic activities) are much higher than previously assumed. These findings have been made in recent decades by isotope analysis (Ciric et al, 2016; Bottyán et al 2017).

The average quantities of precipitation in the warm semester correlates well with the altitude, so the quantities increase from the low areas to higher altitudes. The lowest average quantities of the semester are produced at the pluviometric stations on the Prut valley, at Prisacani and Drânceni. At the Huși weather station, the precipitations also registered lower average values, of 316 $\mathrm{mm}$, against the background of the local characteristics represented by the foehn processes (fig. 3).

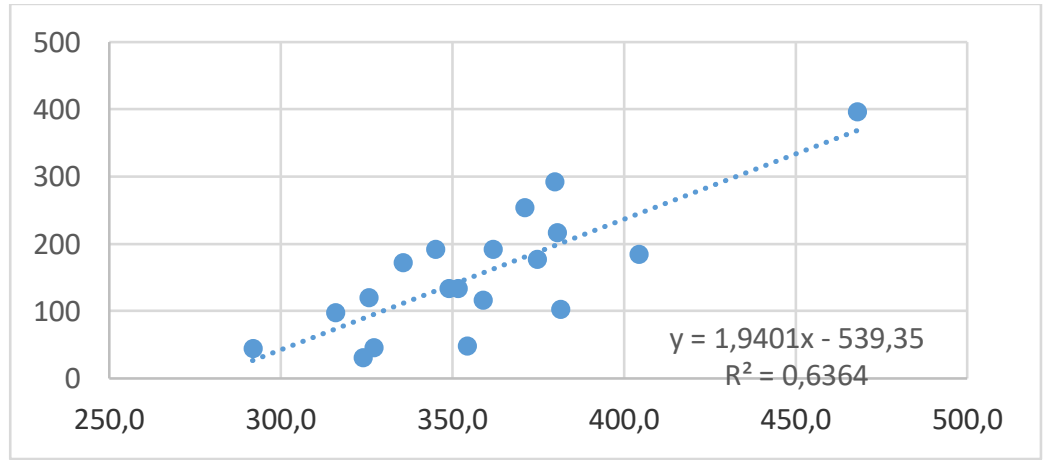

Fig. 3. Correlation of atmospheric precipitation with altitude in the warm semester (1961-2016) 
The maximum values occur in the high areas of the southwest and west of the area, west of the studied area, Roman and Bacău, west of the Central Moldavian Plateau, Lipova and Băcești, but especially on the northern part, where, at Bârnova were recorded the maximum at the level of the plateau, an exceptionally high value for the Moldovan Plateau, an amount of $468.0 \mathrm{~mm}$.

The precipitation regime and the large quantities in the warm semester can be explained against the backdrop of the cyclonic barrel centers that carry wet air masses from the Atlantic, but during the warm semester the precipitations are largely convective, under the cyclonic barrel regime against a highly moisture active surface and an increase in the temperature value that can cause convective precipitation, hence the uneven character of the precipitation.

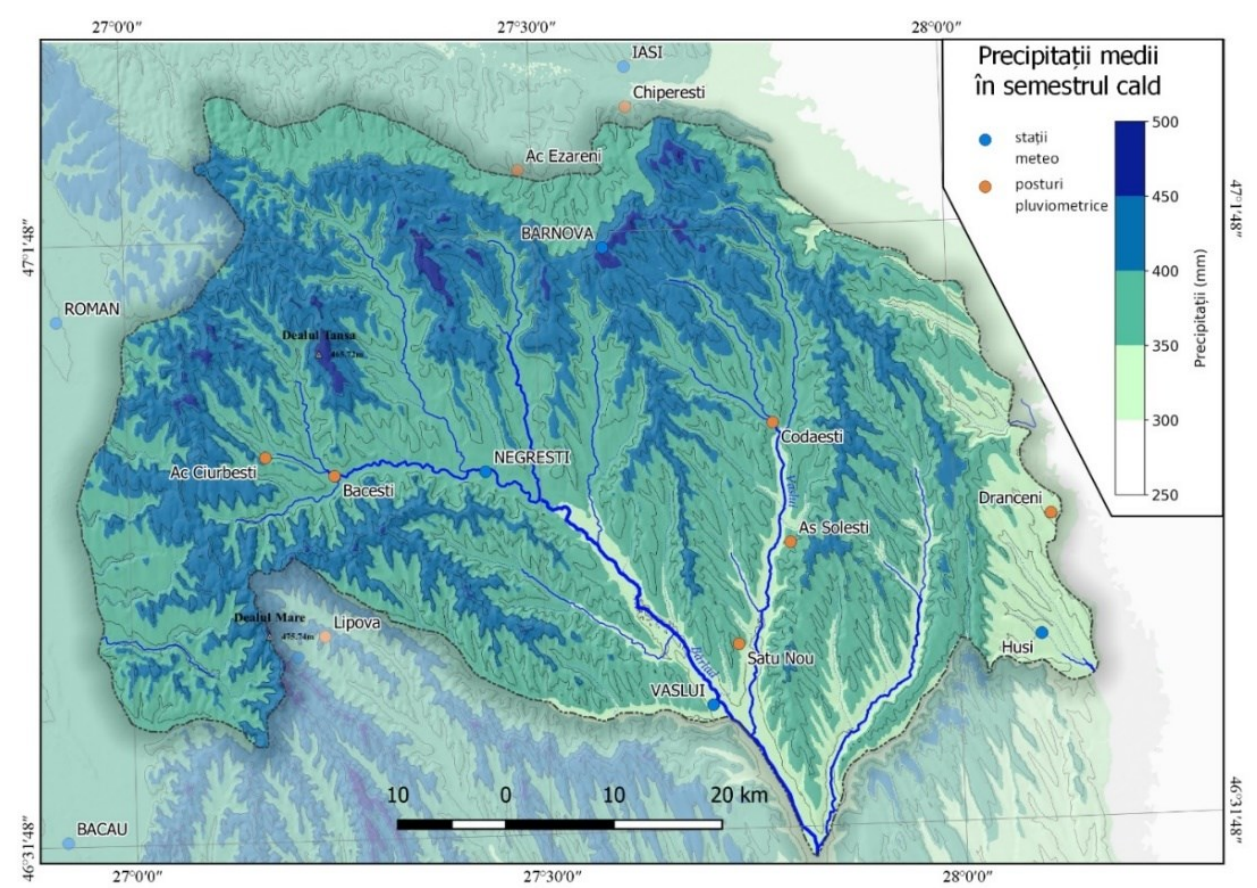

Fig. 4. Warm semester average precipitation distribution in the Central Moldavian Plateau (1961-2016)

The large amounts of rainfall during the warm semester is a positive aspect from the point of view of the agro-climatic potential, the water requirement being largely during the vegetation period. In the warm semester average quantities are almost double compared to the cold semester, and especially during the summer seasons, from June to August when convective processes are 
maximum against the background of the strong heating of the underlying surface. At the Bârnova station, that has a special location, the quantities of the hot semester reach two thirds of the average annual quantities for stations from lower altitudes such as Prisăcani or Drânceni (Fig. 4).

Cold semester. The precipitations in the cold semester occur in a small amount, of about $50 \%$ of the value of those measured in the warm semester (Tab. 3 and Fig. 5), and the maximum monthly averages occur from October to December, and then to decrease in the months January and February - the months with the lowest annual rainfall. The correlation with the altitude is good, but it does not reach the coefficients of the warm semester.

Tab.3. Average of the precipitation amounts (mm) in the cold semester (1961-2016)

\begin{tabular}{|c|c|c|c|c|c|c|c|}
\hline Station & Prisăcani & Drânceni & Leova & Chiperești & Huși & Iași & Vaslui \\
\hline Average & 161.2 & 168.3 & 199.5 & 177.8 & 171.4 & 191.4 & 185.2 \\
\hline Station & Negrești & SatuNou & Bacău & Ciurbesti & Ezareni & Solești & Roman \\
\hline Average & 160.2 & 208.0 & 177.1 & 171.1 & 176.7 & 157.2 & 145.6 \\
\hline Station & Codăești & Bârlad & Lipova & Băcești & Bârnova & & \\
\hline Average & 181.5 & 179.2 & 196.7 & 187.8 & 274.6 & & \\
\hline
\end{tabular}

As we can observe on the Fig. 5, the distribution of precipitations of both semesters has a predominance towards the warm semester at the expense of the cold semester, with percentage differences depending on the geographical location within the plateau.

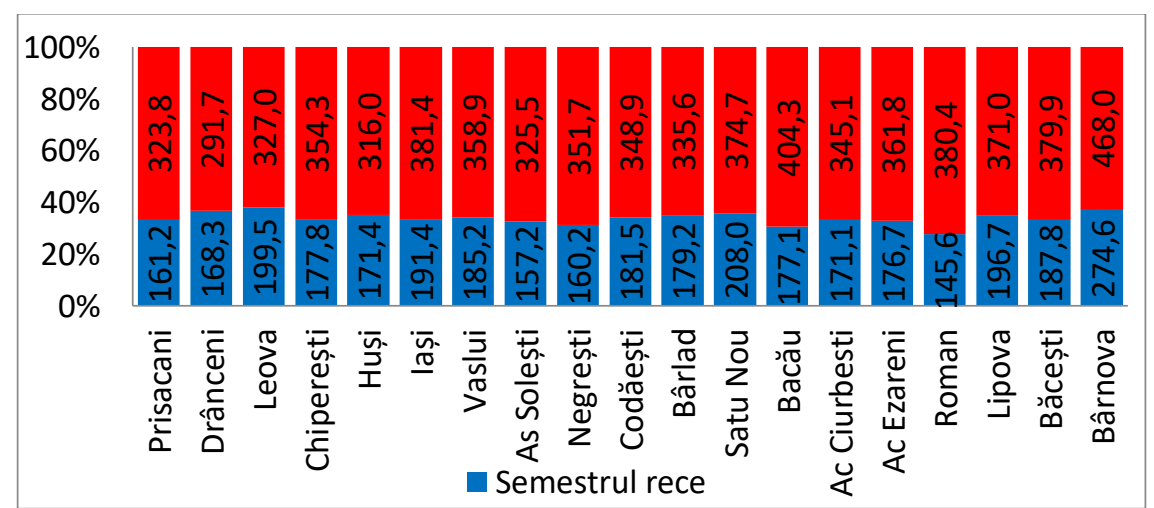

Fig. 5. Semestrial quamtity of the precipitation average in the Moldavian Central Plateau 
The differences generated by the genetic factors during both warm and cold semesters are large for a plateau area having in mind the altitude difference of only $450 \mathrm{~m}$. The spatial distribution of the precipitation in the cold semester is shown in Fig. 6. The weight of the semestrial average of the precipitation quantities is quite uneven at the level of the plateau, first of all between the two semesters, the warm one has a greater weight than the cold one at all the stations, but also spatially.

Another aspect of the non-uniformity is given by the fact that the semester occupies a different weight depending on the geographical area, so that from a longitudinal point of view, the cold semester only occupies $27 \%$ of the average annual precipitation in the western part of the studied area, in the Culoir of Siret, at Roman, and to the east of the studied area, on the valley of Prut river, the average quantity of the cold semester occupies a weight of $38 \%$ the average amount of precipitation at annual level (Leova).

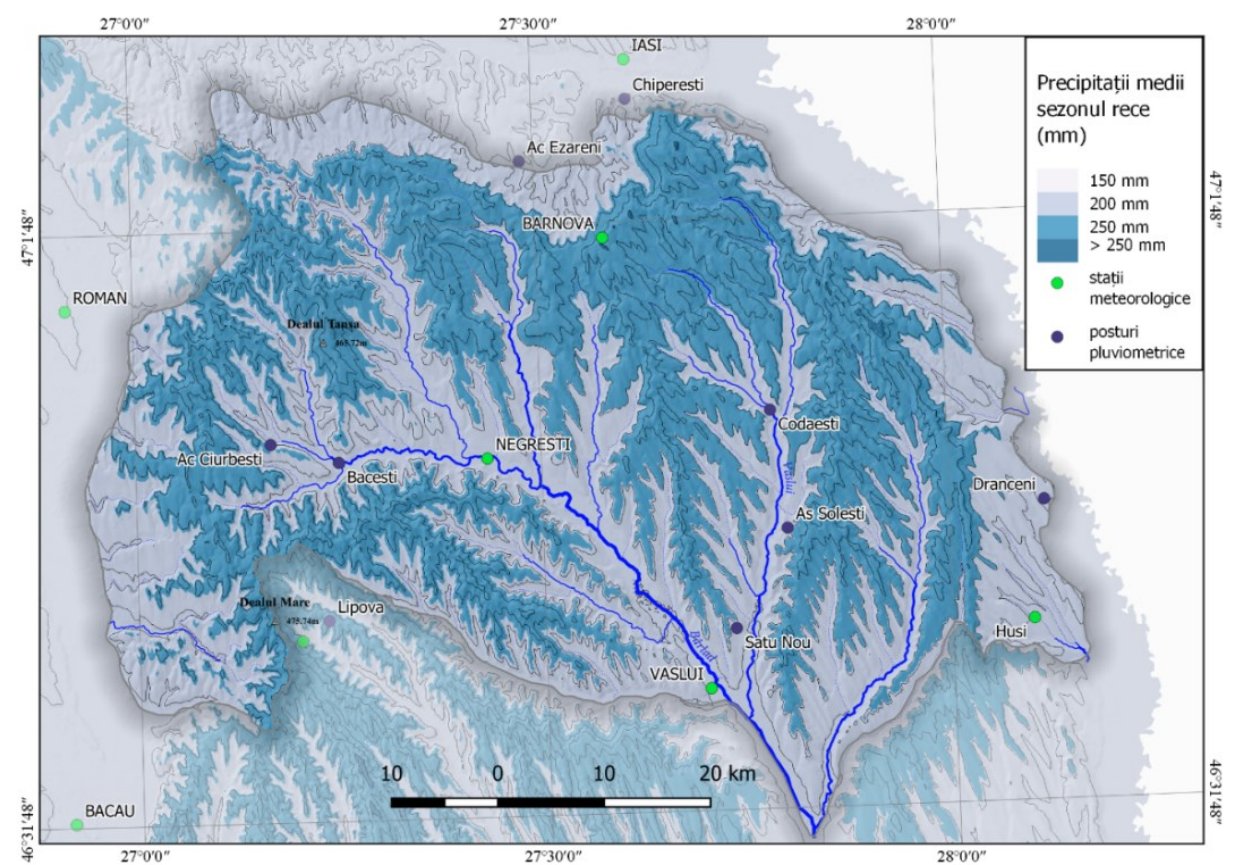

Fig. 6. Cold semester average precipitation distribution in the Central Moldavian Plateau (1961-2016)

\section{Seasonal regime}

On a seasonal level, winter occupies the lowest weight of the annual average of the precipitation amount, between 11\% (Roman) and 16\% 
(Huși). The seasonal distribution of precipitations shows an interesting aspect in that the weight of the spring season, that is approximately the same across the surface of the plateau, with a percentage between $19 \%$ at the pluviometric station Plopana, located in south of the plateau, and 23\% at the Bârnova weather station (Fig. 7).

Summer season has recorded highest weight (43\%), as a result of the aridity influence, with maximum values in the west and south of the Central Moldavian Plateau, respectively at Roman and Plopana, which means a high influence of continentalism generated by the orographic shelter.

Of the total average amounts of rainfall over the course of a year, almost half fell in the summer season, and in successive order, spring season weight of $26 \%$, autumn season with $21 \%$ and finally in winter season with the lowest weight of the total precipitation amount. (fig. 7).

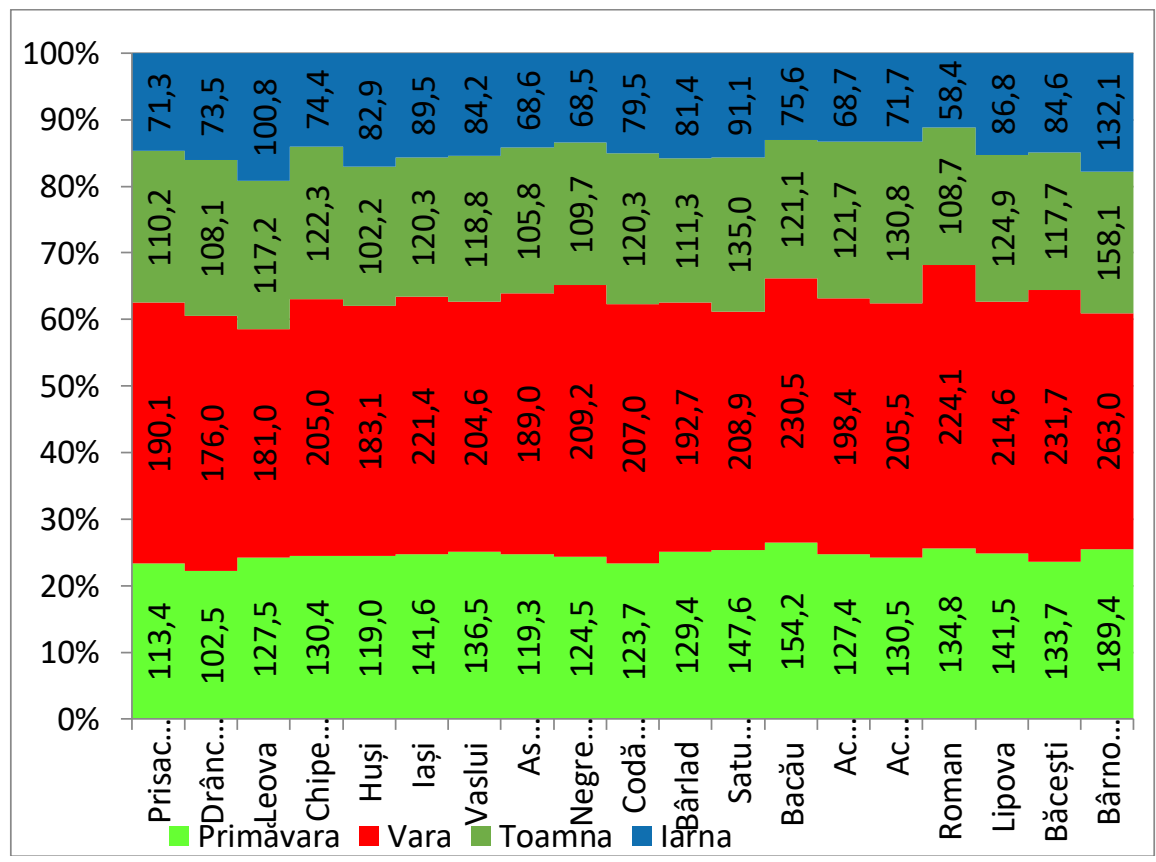

Fig. 7. Seasonal weight of the precipitation amount (1961-2013)

\section{Monthly regime}

During the year, the precipitations amount has a distribution with a minimum in February (at some stations, in January), then increases towards 
summer, with a maximum average in June (at one station, Bacău, in the Siret Culoir, in July), decreasing to the end of the year. The changes from the minimum rainfall in the winter months to the summer months occur through a threshold between March and April, when we could observe the values sharply increasing.

In February, the precipitations register the lowest amount within the year, and from a plateau distribution point of view, lower values are recorded at the stations on the western side, near to Negrești on the valley of Bârlad river, and on the western side of the plateau, along of Siret corridor, at Roman station, and the higher rainfall occurred on the low altitude areas (Huși, Vaslui), and the east, north-east of the plateau, on the Prut valley.

The annual regime of the monthly quantities average was characterized by large quantities in the months of late spring and summer, the maximum being placed in June, followed by July and a minimum in the cold season, in February, followed by January (Tab. 4).

Tab. 4. Monthly average of the precipitation at the meteorological stations and pluviometric stations in the Central Moldavian Plateau (1979-2016)

\begin{tabular}{|c|c|c|c|c|c|c|c|c|c|c|c|c|c|}
\hline Stația & I & II & III & IV & V & VI & VII & VIII & IX & X & XI & XII & Year \\
\hline Prisacani & 23.4 & $\mathbf{2 2 . 4}$ & 26.3 & 37.0 & 50.1 & $\mathbf{7 9 . 3}$ & 68.6 & 42.2 & 46.6 & 34.8 & 28.8 & 25.5 & $\mathbf{4 8 5 . 0}$ \\
\hline Drânceni & 24.4 & $\mathbf{2 1 . 5}$ & 24.1 & 36.3 & 42.1 & $\mathbf{6 6 . 4}$ & 63.7 & 45.9 & 37.4 & 35.3 & 35.4 & 27.6 & $\mathbf{4 6 0 . 1}$ \\
\hline Leova & 32.6 & $\mathbf{3 0 . 9}$ & 29.8 & 40.2 & 57.5 & $\mathbf{6 4 . 9}$ & 61.2 & 54.9 & 48.3 & 33.3 & 35.6 & 37.3 & $\mathbf{5 2 6 . 6}$ \\
\hline Chiperești & 23.9 & $\mathbf{2 1 . 8}$ & 29.1 & 46.5 & 54.8 & $\mathbf{8 4 . 0}$ & 72.8 & 48.2 & 48.0 & 40.6 & 33.7 & 28.7 & $\mathbf{5 3 2 . 1}$ \\
\hline Huși & $\mathbf{2 5 . 8}$ & 27.7 & 26.0 & 40.9 & 52.1 & $\mathbf{7 5 . 8}$ & 59.6 & 47.8 & 39.8 & 30.4 & 32.0 & 29.4 & $\mathbf{4 8 7 . 3}$ \\
\hline Iași & 30.3 & $\mathbf{2 8 . 1}$ & 31.7 & 49.4 & 60.5 & $\mathbf{8 8 . 4}$ & 78.2 & 54.8 & 50.1 & 35.3 & 34.9 & 31.1 & $\mathbf{5 7 2 . 8}$ \\
\hline Vaslui & 26.7 & $\mathbf{2 5 . 8}$ & 29.1 & 43.6 & 63.8 & $\mathbf{7 6 . 7}$ & 73.0 & 54.9 & 46.9 & 36.4 & 35.5 & 31.7 & $\mathbf{5 4 4 . 1}$ \\
\hline Ac. Solești & 21.4 & $\mathbf{2 1 . 1}$ & 25.0 & 35.2 & 59.1 & $\mathbf{7 0 . 8}$ & 66.2 & 52.0 & 42.3 & 34.0 & 29.6 & 26.1 & $\mathbf{4 8 2 . 7}$ \\
\hline Negrești & $\mathbf{2 1 . 3}$ & 21.4 & 25.7 & 41.9 & 56.9 & $\mathbf{8 2 . 2}$ & 72.2 & 54.8 & 43.7 & 36.6 & 29.4 & 25.8 & $\mathbf{5 1 1 . 9}$ \\
\hline Codăești & 26.1 & $\mathbf{2 3 . 4}$ & 29.4 & 40.0 & 54.2 & $\mathbf{8 0 . 1}$ & 71.8 & 55.0 & 47.7 & 38.6 & 34.0 & 30.0 & $\mathbf{5 3 0 . 4}$ \\
\hline Bârlad & 25.8 & $\mathbf{2 5 . 1}$ & 28.5 & 43.3 & 57.6 & $\mathbf{7 4 . 8}$ & 64.5 & 53.4 & 42.0 & 36.3 & 33.0 & 30.5 & $\mathbf{5 1 4 . 8}$ \\
\hline Satu Nou & 29.6 & $\mathbf{2 7 . 3}$ & 35.4 & 52.1 & 60.1 & $\mathbf{8 4 . 4}$ & 72.4 & 52.2 & 53.6 & 43.8 & 37.6 & 34.2 & $\mathbf{5 8 2 . 7}$ \\
\hline Bacău & 23.6 & 24.4 & 29.7 & 52.4 & 72.1 & 86.4 & $\mathbf{8 7 . 9}$ & 56.2 & 49.3 & 40.0 & 31.8 & 27.6 & $\mathbf{5 8 1 . 4}$ \\
\hline A Ciurbești & 23.2 & $\mathbf{2 0 . 0}$ & 29.5 & 44.6 & 53.3 & $\mathbf{7 8 . 5}$ & 68.9 & 51.0 & 48.7 & 40.3 & 32.6 & 25.6 & $\mathbf{5 1 6 . 2}$ \\
\hline Ac Ezareni & 23.9 & $\mathbf{2 0 . 7}$ & 28.8 & 47.4 & 54.3 & $\mathbf{8 8 . 1}$ & 64.9 & 52.5 & 54.6 & 39.4 & 36.7 & 27.1 & $\mathbf{5 3 8 . 6}$ \\
\hline Roman & 18.0 & $\mathbf{1 7 . 7}$ & 23.1 & 48.0 & 63.7 & $\mathbf{8 5 . 3}$ & 81.7 & 57.1 & 44.6 & 36.2 & 27.9 & 22.7 & $\mathbf{5 2 6 . 0}$ \\
\hline Lipova & $\mathbf{2 6 . 3}$ & 28.5 & 34.1 & 48.0 & 59.3 & $\mathbf{8 5 . 6}$ & 71.3 & 57.7 & 49.0 & 45.3 & 30.5 & 32.0 & $\mathbf{5 6 7 . 8}$ \\
\hline Băcești & 27.7 & $\mathbf{2 6 . 2}$ & 30.4 & 46.9 & 56.4 & $\mathbf{9 9 . 7}$ & 76.3 & 55.8 & 44.8 & 41.7 & 31.2 & 30.7 & $\mathbf{5 6 7 . 7}$ \\
\hline Bârnova & 45.1 & $\mathbf{4 0 . 6}$ & 45.8 & 64.6 & 79.0 & $\mathbf{1 0 1 . 5}$ & 90.4 & 71.0 & 61.4 & 51.3 & 45.4 & 46.5 & $\mathbf{7 4 2 . 6}$ \\
\hline
\end{tabular}


At the rainfall stations Solești, Bârnova, Lipova and Plopana, the lowest monthly average is also recorded in February, but the differences compared to January are negligible. The monthly average for all the meteorological stations and the rainfall stations in the Central Moldavian Plateau are projected on the graph at Fig. 8.

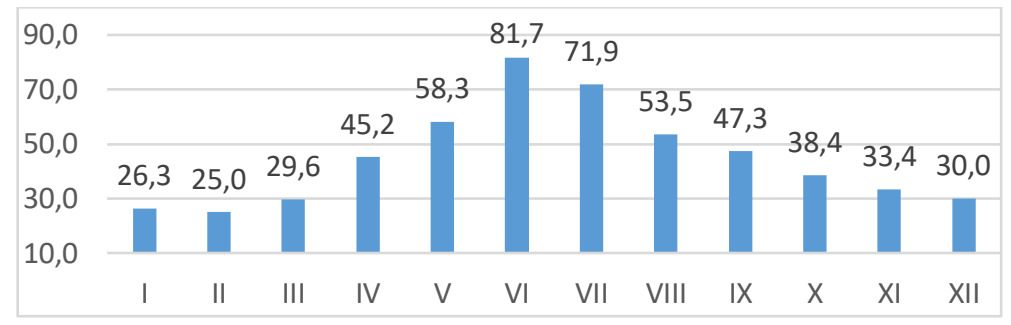

Fig. 8. Monthly average of the precipitation in the Central Moldavian Plateau (1961-2016)

\section{Conclusions}

The annual regime of the monthly precipitations is characterized by large quantities at the end of spring and during summer, the maximum being placed in June, except in Roman where the maximum is registered in July, and a minimum in the cold seasons, in January for Huși, Vaslui, Plopana, Negrești and in February at Iasi, Roman and Leova stations.

The precipitation regime and the large quantities in the warm semester are mainly generated by the cyclonic barrel centers that carry wet air masses from the Atlantic, but during the warm semester the precipitations are largely convective, due to the high humidity of the active surface, and an increase in temperature value that can cause convective precipitation, hence the uneven character of precipitation. The weight of the semester amounts of precipitation is uneven at the level of the plateau, yearly but also between the two semesters, the warm one has a higher amount than the cold one, at the most stations. Another aspect of the unevenness is given by the fact that the semester occupies a different weight from the average annual amount of precipitation, depending on the geographical area, so that from west to east the weight of the cold semester increases, occupying only $27 \%$ of the amount of precipitation at the level annually in the Siret Corridor, in Roman, and in the eastern side of the plateau, the weight of the cold semester reaches $38 \%$ against the warm one.

At the seasonal level, the distribution of precipitation presents an interesting aspect where the weight of the spring season is approximately the 
same for the entire surface of the plateau, with around $20-21 \%$. The quantities of precipitation that fall in the winter season occupy the lowest weight average, between $12 \%$ and $16 \%$. In the summer season the highest weight was registered of $43 \%$ at Plopana station.

Of the total amount of precipitation during a year, about $40 \%$ fall in the summer season, and in successive order it is the spring season with a percentage of $26 \%$, the autumn season with $21 \%$ percent and the lowest in the winter season.

\section{Bibliography:}

1. Apăvăloae, M., Apostol, L. (1997), Caracteristici ale cantiăților de precipitații în 24 ore in Subcarpații Moldovei și Culoarul Siretului, Lucr. Sem. Geogr. „Dimitrie Cantemir", Iaşi, nr. 13-14 (1993-1994).

2. Apostol, L. (1987)Consideraţii asupra raportului dintre cantităţile semestriale de precipitaţii în România, Lucr. Sem. geogr. „D. Cantemir”, nr. 7/1986, Iaşi, pg. 5364

3. Apostol, L. (2000), Precipitaţiile atmosferice în Subcarpaţii Moldovei, Edit. Univ. Suceava.

4. Apostol, L. (2004) Clima Subcarpaților Moldovei, Editura Universității Suceava,. 5.

5. Apostol, L. (2008), The Mediterranean cyclones - The role in ensurig water resources and their potential of climatic risk, in the East of Romania, ,Present environment and sustainable development”, vol. 2, Edit. Univ. „Al. I. Cuza”, Iaşi, ISSN 18435971.

6. Apostol, L., Apăvăloae, M. (1985), Consideraţii asupra cantităţilor de precipitaţii în Câmpia Fălciului şi în Depresiunea Huşi, Lucr. Sem. geogr. „D. Cantemir”, nr. 5/1984, Univ. „Al. I. Cuza”, Iaşi, pg. 123-127.

7. Apostol, L., Amăriucăi, M. (2005) The exceptional torrential rain form the summer of 2004 year, in the context of the 1991-2004, period Romanian Journal of Climatology, Edit. Univ. ,Al. I. Cuza”, Iaşi, pg. 47-57, ISSN 1841-513X.

8. Bottyán, E., Czuppon, G., Weidinger, T., Haszpra, L., Kármán K. (2017), Moisture source diagnostics and isotope characteristics for precipitation in east Hungary: implications for their relationship, Hydrological Sciences Journal, https://doi.org/10.1080/02626667.2017.1358450.

9. Budui, V. (2007), Varietatea spațio-temporală a precipitațiilor atmosferice în partea vestică a Podișului Central Moldovenesc, Analele Universității „Ş,tefan cel Mare” Suceava. Secțiunea Geografie, anul XVI-2007.

10. Ciric, D., Stoianovic, M., Drumond, A., Nieto, R., Gimeno, L. (2016), Tracking the Origin of Moisture over the Danube River Basin Using a Lagrangian Approach, Atmosphere, 7(12): 162. https://doi.org/10.3390/atmos7120162

11. Davidescu, G. (1973), Particularităţile regimului pluviometric din zona oraşului Vaslui, An. Șt. Univ. „Al. I. Cuza”, Iaşi, s. II c, t. XIX, pp. 155-157. 
12. Erhan, E. (1988), Considerații asupra precipitațiilor atmosferice din partea de est a României, Lucrările Seminarului Geografic "Dimitrie Cantemir" Nr.8, 1987.

13. Hârjoabă, Crețu, Lil1984), Tentația convecției, Anal. Univ. „Al. I.Cuza”, ser. nouă, secț.II, b, geol.-geogr., t.XXX, Iași.

14. Larion, D. (2004), Unele particularități ale regimului pluviometric în Podișul Central Moldovenesc, Lucrările Seminarului Geografic "Dimitrie Cantemir" Nr.23-24/2004.

15. Mihăilă, D. (2006), Câmpia Moldovei. Studiu climatic, Editura Univ. Suceava.

16. Patriche, C.V. (2005), Podişul Central Moldovenesc dintre râurile Vaslui şi Stavnic, Editura "Terra Nostra", Iaşi. 
